\title{
EU migrant retention and the temporalities of migrant staying: a new conceptual framework
}

\author{
Helena Hof ${ }^{1 *}$ (D, Simon Pemberton ${ }^{2}$ and Emilia Pietka-Nykaza ${ }^{3}$
}

\author{
*Correspondence: Helena.hof@uzh. \\ ch \\ ${ }^{1}$ Department of Japanese Studies, \\ Institute of Asian and Oriental \\ Studies, University of Zurich, \\ Zürichbergstrasse 4, $\mathrm{CH}-8032$ Zürich, \\ Switzerland \\ Full list of author information is \\ available at the end of the article
}

\begin{abstract}
Challenges of weak economic growth, population decline, and labour shortages led many countries across the world to introduce immigration policy changes in order to attract foreign migrants. This paper focuses on Japan (Tokyo) and the UK (Birmingham, Edinburgh and Glasgow) given common concerns over long term demographic trends and the burgeoning lack of labour supply in particular sectors of the economy through use of foreign labour. The paper shifts the focus from efforts focused on attracting and selecting foreign labour to the retention of such individuals. Drawing on research with EU migrants in Japan and the UK, the paper highlights how staying may occur after a period of mobility, rather than only being of relevance to those who never left their home region. The paper develops a new conceptual framework, which helps to identify different dimensions that shape migrant staying as a temporal process. It is highlighted how staying is shaped incrementally and facilitated or undermined over time in relation to the reciprocal importance of diverse assets, anchors and the changing biographies of migrants and the places in which they live - as well as the relational aspects of migrants' 'linked lives'.
\end{abstract}

Keywords: Migrant staying, Temporal, Assets, Anchors, Biographies, Linked lives, Retention

\section{Introduction}

This paper provides new insights into the influences shaping the temporalities of migrant staying in areas of increasing superdiversity. Whilst migration research has shifted from assuming permanent settlement as the ultimate outcome of movement, to tracing repeated movement, mobility, and even hyper-mobility (Sheller and Urry 2006), there has been much less focus on migrants' experiences and practices associated with immobility and 'staying' in place without denying the potential of re-migration (Thomas et al. 2015; Salamońska and Recchi 2016). Through drawing on recent research with $79 \mathrm{EU}$ migrants who came to Japan (Tokyo) and the UK (Edinburgh, Glasgow and Birmingham) in the last ten years, this paper illustrates how staying is an active agent-centred process which is often an integral element of a life strategy involving other people or places, that involves a constant weighing up by migrants of their

(c) The Author(s). 2021 Open Access This article is licensed under a Creative Commons Attribution 4.0 International License, which permits use, sharing, adaptation, distribution and reproduction in any medium or format, as long as you give appropriate credit to the original author(s) and the source, provide a link to the Creative Commons licence, and indicate if changes were made. The images or other third party material in this article are included in the article's Creative Commons licence, unless indicated otherwise in a credit line to the material. If material is not included in the article's Creative Commons licence and your intended use is not permitted by statutory regulation or exceeds the permitted use, you will need to obtain permission directly from the copyright holder. To view a copy of this licence, visit http://creativecommons.org/licenses/by/4.0/. 
current situation vis a vis potential future opportunities and challenges. Processes of staying may therefore lead to permanent settlement, but not always. Such analysis suggests the usefulness of a new conceptual framework for understanding migrant staying as an on-going process shaped not only by the actions of others but also in relation to ever-evolving individual and place biographies and the accumulation of different types of 'assets' (Moser 2007, 2008) and 'anchors' (Grzymala-Kazlowska 2016). In so doing, the paper identifies the crucial importance of time and temporalities of staying, building upon earlier work by Cwerner (2001) and contributing to more recent debates exploring the importance of time in migration processes (Robertson 2014, 2015; Sheller 2019).

Migrant retention is important when considering the significance of migrant staying in relation to broader migration policies. Issues of retention are crucial if migration policies which have been designed to alleviate lack of labour supply in their national labour markets are to be effective. In this paper we explore the influences shaping migrant staying in Japan and the UK. We do so by focusing on a particular type of migration, namely EU migration. To date, EU migration in Europe has often been described as "liquid" and "open ended" with EU migrants not necessarily remaining 'fixed' in destination countries (see Ryan 2018; Collett 2013). EU migrants have been described as 'regional free movers' that are more likely to engage in temporary, circular or transnational mobility that is governed by economic demand, than in long-term, permanent migration (Favell 2008, p. 703). Similarly, in a non-Western context, EU migration has been described as highly mobile (Beaverstock 2002; Hof 2019).

Consequently, in contrast to existing studies which have investigated the mobility of EU migrants (Recchi and Favell 2009; Engbersen et al. 2017), this paper explores the influences shaping staying among EU migrants in Japan (Tokyo) and the UK (Glasgow, Edinburgh and Birmingham). Challenges around ageing populations, declining economic growth and sector-specific labour market shortages have led many governments - including those in Japan and the UK - to introduce a range of migration policy measures which act as a 'tap' that can be switched 'on' or 'off' according to the requirement of national labour markets (Anderson 2007). Yet, the effectiveness and sustainability of such policy measurements - at least in part - depend on migrant retention. Such arguments have direct relevance to Japan and the UK despite demographic and migration trends differing considerably within and between the two countries.

In the UK, net migration is a major component of population growth. At present, the foreign-born population constitutes $14 \%$ of the UK total, although this varies between England (16\%), Scotland (9\%), Northern Ireland (7\%) and Wales (6\%) (Vargas-Silva and Rienzon 2020). Furthermore, the impact of migration on future population trends is forecast to differ considerably across the four UK constituent nations. In Northern Ireland, natural change without net migration is projected to be the main driver of future population growth by 2035 ( $+4 \%$ increase in population). In England, the equivalent figure is $+0.6 \%$. But in Scotland and Wales populations are due to decline by $8.1 \%$ and $5.3 \%$ respectively without net international migration or cross border migration from other parts of the UK (Office for National Statistics (ONS) 2019). Therefore in Scotland, the Scottish Government has emphasised how the country faces a distinct set of immigration challenges and with the dominant focus being on attracting and retaining international migrants per se (Scottish Government 2018). This is in 
contrast to other parts of the UK, and especially England, where the emphasis has been on restricting the scale of international migration to only the highest skilled migrants in the main (Migration Advisory Committee 2020).

In Japan - and similar to many parts of rural Scotland and Wales - the overall population has been declining rapidly. Population trends project a steep decrease from 126 million citizens in 2018 to 88 million in 2065 (National Institute of Population and Social Security Research 2017). Facing one of the most severe labour shortages amongst OECD countries in the early 2000s, Japan has therefore focused on promoting the reception of so-called highly skilled foreign professionals through new visa programmes (Ozgen et al. 2019; Oishi 2012) and since 2018, also on so-called 'Specified Skilled Workers' which target 14 sectors with current labour shortages (Lessard-Phillips et al. 2019). With just over $2 \%$ of the population being foreigners in 2018, the proportion of international migrants is still very low compared to most other industrial countries. Yet, as Liu-Farrer (2020) argues, the slow but steady increase of foreign nationals over time, and sharp increase since 2010, has made Japan a de facto immigrant country. Hence in similarity to some parts of the UK (and notably Scotland), Japan has increasingly emphasised the need for not only attracting foreign labour, but also to retain such individuals (Oishi 2020). However, evidence suggests that the issue of migrant retention, and the importance of staying therein, require more attention (Holbrow and Nagayoshi 2018; Lessard-Phillips et al. 2019). For instance, in Japan, even the supposedly "desired", so-called highly-skilled migrants often lack support services and do not feel comfortable to stay (Oishi 2012; Tseng 2020).

\section{Temporalities of migrant staying}

A focus on the increasing diversification of (migration-driven) population diversity (Vertovec 2007) has been accompanied by an interest in developing a more nuanced understanding of issues relating to migrants' mobilities and subsequent adaptation and settlement processes (Grzymala-Kazlowska and Phillimore 2018). Given that migrationdriven population diversity has involved the increasing super-mobility of populations and with individuals driven by multiple non-linear modes of migration which include secondary migration, circular migration, onward migration and internal migration (Valentine and Sadgrove 2012; Robertson 2015) - there is a need to re-think mobility and indeed, immobility, as unfolding practices over time rather than as a discrete event.

Staying - or lack of mobility - according to Faist (2013), was often associated with stasis, decline, disadvantage and a lack of agency. In a rural context, immobility and staying have overwhelmingly been connected with a failure to leave (Looker and Naylor 2009) and with studies of migration and mobility devaluing the agency involved with staying (Coulter et al. 2013). Such perspectives need to be challenged in rural and urban contexts. Thomas et al. (2015) argue that immobility and staying have hitherto been largely neglected to date as immobility and staying have been treated as residual to mobility and migration. Stockdale and Haartsen (2018) have advocated the need for a greater focus on immobility and staying and to re-conceptualize staying as an active process subject to continual (re-)negotiation. Nevertheless, most literature on staying to date has focused on those who have not left their home region or who did leave but stayed in respect of mental connections with their home region (Stockdale et al. 2018). 
Thus staying - as we will show - needs to be understood as an ongoing practice which may occur in the context of immobility or following mobility. By emphasising individual's practices defined as everyday acts, interactions and performances of 'doing' (Holdsworth 2013), such an approach redirects the focus from migrant's intentions or length of stay in destination country to the ways in which migrants "do" or "practice" their stay. This provides a useful perspective for analysing the fluid, open-ended events, experiences and practices associated with staying, and which may or may not lead to permanent settlement.

The importance of place in shaping staying also needs to be recognized. Studies of migration and mobility have highlighted how places are the product of 'roots' and 'routes' and are the sites of multiple identities and histories (Massey 2005; Pemberton and Phillimore 2018). A critical mobilities approach has identified how in an increasingly hyper-mobile world places are relational, not bounded, never finished and involving an intersection of flows, people and objects - a "constellation of processes" (Massey 2005, p. 141). In addition, the choice, or force, to stay demonstrates the importance of the features of particular places as well as how different aspects of place shape the (re)negotiation of staying. This may include the interplay of structural (for example, access to employment or education), spatial (proximity of resources), civic (rights and entitlements) and territorial (place-specific actions by migrants) conditions that shape processes of attachment and belonging (Ryan 2018). These structural opportunities can support (or hinder) the generation of both tangible and intangible assets in the place of residence.

Tangible assets include income, housing, education and health. Intangible assets, on the other hand, refer to social, psychological and political assets, such as household and community networks; rules, norms and 'reciprocity' (Moser 2007). The accumulation of diverse assets may provide valuable resources but also 'roots' for migrants in their place of residency that in the longer term may facilitate staying. The accumulation of assets is a dynamic process and with assets acting as a 'stock' which provide migrants with the capability and agency to act and use such resources in a diverse range of situations to make long-term plans (Moser 2008, p. 62; Giniewicz and Castiglione 2011). However, the values of assets may rise or fall over time and hence intersect with the changing biographies of individuals and the places in which they work and live to shape processes of staying. Whilst the relationship between mobility and place have been subject to considerable discussion, the everyday lives and experiences of stayers have yet to be adequately researched, nor the different aspects of place and their role in the staying process (Stockdale and Haartsen 2018).

Further to the role of place in shaping migrant's experiences of staying, migration studies tend to emphasise the role of migrant networks, including the density and intensity of such networks and transnational and interconnected social ties (for example, through friends, family or children) as important drivers for mobility as well as experiences of staying. Migration networks (Ryan et al. 2008), as well as family migration (Ryan 2011; White 2011), have been identified as key drivers facilitating and shaping patterns of EU migration to the UK but also informing relational practices of embedding in destination countries (Ryan 2018). These networks can create intangible assets that provide valuable resources as well as 'roots' for individuals in their place of residence that in the longer term may facilitate settlement processes. However, life course 
theories also draw our attention to how lives are linked over space and time (Elder 1994). Consequently, the staying practices of individuals may be influenced not just in relation to networks but also through 'linked lives': the ways in which staying or moving is shaped by different family members (e.g. parents, partners or children), peers, or the home community (Stockdale and Haartsen 2018). Decisions to stay, however, can be in constant flux and change through the life-course and informed by individual biographies and how these are entangled with those of others (Coulter and Scott 2015). As such, the nature of migrants' 'linked lives' and the actions and decisions of others whether family, friends, partners or others - demands further attention in migrant processes of staying.

Mobility and immobility are as much concerned with time as with place and space, as all migration processes have complex temporal dimensions (Cwerner 2001; Griffiths et al. 2013; Robertson 2015; Sheller 2019). These temporal dimensions refer to the way in which the nation-state seeks to manage immigration as well as migrants' evolving social and cultural practices (Cwerner 2001). It is not the actual duration of mobility or immobility that is significant, but the way in which time and the temporality of migrant's experiences and practices shape the structures of migrant biographies and the places in which they reside, as well as vice versa. Moreover, staying is a non-linear process as immigrants do not settle gradually and evenly over time; for example, certain life events (divorce, bereavement) or circumstances (change of employment or retirement) may result in onward mobility. Indeed, they may 'age in place' - as reflected in discussions of ageing in migration (for example, see King et al. 2017) - and which can influence immigrant's decisions to 'return home' in order to access care through family, relatives and / or friends (Sampaio et al. 2018). Thus, Halfacree and Rivera (2012) emphasize that migrants are 'contextual' subjects with their biographies changing with time and with place, along with priorities, needs and desires.

Nevertheless, 'time' has multiple meanings including time as duration, discipline, politics, rhythm, flexible, suspension, liminal (Sheller 2019, p. 337) and involving flows and moments; rhythms and cycles; synchronicity and disjuncture (Griffiths et al. 2013, p. 2). Taking into consideration these multiple meanings and forms of 'time', in this paper we use Robertson 2015, p. 1918) work to refer to time and temporality in the context of staying as a subjective sense of 'lived time'. Hence insofar as time manifests itself in human experience, we seek to illustrate how multiple forms of time shape the complexity associated with migrant's experiences of staying.

Finally, further to the role of place, assets, 'linked lives' and time in shaping experiences of staying, the psychological aspects of staying in destination countries warrant further consideration (Erdal and Oeppen 2013). In this respect, the concept of 'anchoring' is useful. Developed by Grzymala-Kazlowska (2016, 2018) it demonstrates how migrants search for 'footholds' and points of reference that allow them to acquire socio-psychological stability and security in order to adapt and feel 'settled down' in a new or substantially changed life environment (Grzymala-Kazlowska 2016). However, the temporalities of anchoring have been less discussed to date. As a result, further investigation is required of how such anchors may change in the context of changing migrant biographies and changing places.

In sum, we know relatively little in respect of the temporalities shaping migrant experiences of staying in a "world characterized by mobility" (Stockdale and Haartsen 2018, p. 3). 
Our paper therefore draws on research conducted with EU migrants in three different case study areas in the Japan and the UK. Whilst accepting that there were notable differences in the influences shaping migration, we focus instead on a number of important commonalities in terms of the processes shaping EU migrant experiences of staying in different contexts. These subsequently inform the development of a new conceptual framework which emphasizes the temporal dimensions of migrant staying, reciprocally shaped by the lives of significant others, and the influence of assets, changing biographies and anchors.

\section{Methods}

The paper draws on three major qualitative studies with European migrants who came to Japan (Tokyo) and the UK (Glasgow, Edinburgh and Birmingham). All of the primary data focused on exploring how migrant's experiences in their new country of residence shaped practices of staying. The research received ethical approval from the researcher's respective ethics committee where required (in the UK) and from the doctoral supervisor of the researcher based in Japan. All respondents were given oral and written information about the project, including the option to withdraw after the interview and then asked to sign or orally approve their consent. All data were anonymised.

All of the studies were conducted between 2014 and 2020 with similar qualitative methods employed across each research project, including ethnography, surveying and in-depth interviews (Table 1).

The overall sample of EU migrants across the three case studies was relatively young (between 25 and 44 years old on average) and with roughly an equal number of female and male participants. Individuals were at a relatively early stage of the life-course and with a range of skills and occupation(s) evident. Hence in the context of our sample, there was less reference in the accounts of participants to the importance of ageing in place in shaping practices of staying, although this clearly is an issue that requires further research. Furthermore, in our studies, all migrants held a regular legal status in the destination countries; in the UK, they were entitled to work and reside in the

Table 1 Study details

\begin{tabular}{|c|c|c|c|c|c|}
\hline $\begin{array}{l}\text { Country } \\
\text { and city }\end{array}$ & Methods & $\begin{array}{l}\text { Respondent } \\
\text { gender }\end{array}$ & $\begin{array}{l}\text { Respondent } \\
\text { age }\end{array}$ & $\begin{array}{l}\text { Length of } \\
\text { residence }\end{array}$ & Occupation \\
\hline Japan (Tokyo) & $\begin{array}{l}37 \text { in-depth } \\
\text { interviews, } \\
\text { also follow-up } \\
\text { interviews with } \\
\text { all but six } \\
\text { informants } \\
\text { Ethnographic } \\
\text { observations }\end{array}$ & $\begin{array}{l}19 \text { male } \\
18 \text { female }\end{array}$ & $22-34$ & $\begin{array}{l}\text { Less than } \\
5 \text { years at } \\
\text { time of first } \\
\text { interview }\end{array}$ & $\begin{array}{l}\text { Range of occupations } \\
\text { (e.g. Finance, Architecture, } \\
\text { Engineering, Marketing, } \\
\text { Translation, etc). }\end{array}$ \\
\hline $\begin{array}{l}\text { UK } \\
\text { (Glasgow and } \\
\text { Edinburgh) }\end{array}$ & $\begin{array}{l}24 \text { in-depth } \\
\text { interviews } \\
\text { (including } \\
\text { follow-up } \\
\text { interviews with } \\
\text { half of the sample) }\end{array}$ & $\begin{array}{l}12 \text { male } \\
12 \text { female }\end{array}$ & $25-36$ & $\begin{array}{l}\text { At least } \\
5 \text { years at } \\
\text { time of first } \\
\text { interview }\end{array}$ & $\begin{array}{l}\text { Range of occupations } \\
\text { (e.g. Architecture, HR, } \\
\text { Care worker, Cleaner, } \\
\text { Self-employed etc.). }\end{array}$ \\
\hline UK (Birmingham) & $\begin{array}{l}18 \text { in-depth } \\
\text { interviews } \\
\text { Ethnographic } \\
\text { observations }\end{array}$ & $\begin{array}{l}10 \text { male } \\
8 \text { female }\end{array}$ & $24-44$ & $\begin{array}{l}\text { Less than } \\
5 \text { years }\end{array}$ & $\begin{array}{l}\text { Range of occupations } \\
\text { (e.g. Finance, Marketing, } \\
\text { Distribution, Warehousing, } \\
\text { Self-employed etc.). }\end{array}$ \\
\hline
\end{tabular}


country on grounds of their EU citizenship; in the case of Japan, the migrants were granted work visa. ${ }^{1}$ As a result, due to legal status being 'a given', such factor featured less heavily in shaping individuals' responses, although we do highlight - where relevant - how this shaped the development of assets and anchors.

Equally, there was variance in respect of how long migrants had been in Japan or the UK. Such diversity was important as while drivers for migration, professional qualifications and duration in each country all differed, common experiences that characterised the process of migrant staying were evident and were focused upon in three different urban contexts. In so doing, we were able to consider influences shaping staying for a broad range of individuals and thereby help to inform approaches around migrant retention which have varied according to the perceived value of such individuals in terms of filling either skills or labour shortages.

Interview data were coded collectively using a systematic thematic analysis approach (Guest et al. 2012) to identify the key issues raised by respondents. This involved interpretive code-and-retrieve methods wherein the data were transcribed and codes and an interpretative thematic analysis undertaken using NVivo software. Through combining our data sets we sought to identify key dimensions rather than achieve data saturation or to generalise. Quotations used in this paper were selected on the basis of their ability to illustrate key issues raised by respondents.

\section{Results and analysis}

Based on the review of previous literature on the temporalities of migrant staying and the findings that emerged, results from the studies are organised under three headings: assets, changing biographies of people and places and anchors. Nevertheless, these themes overlap illustrating the complexities and multi-dimensionality associated with migrant's experiences of staying. The relation of the three themes and their implications will be discussed and tied together by proposing a new conceptual framework in the concluding section.

\section{Assets}

The majority of the participants in our three case studies had migrated to their destination country in their early twenties. The relatively young age of initial migration situated our participants within early stages of the life course and allowed us to focus on exploring how decisions to stay were being renegotiated with the onset of new life course events. The transition for many from education to work impacted on the extent to which individuals were seeking to invest and acquire a range of assets during the initial stages of their stay in the destination country. Indeed, key reasons highlighted by individuals for extending their stay were often related to place-specific opportunity structures concerned with securing tangible assets (Moser 2007) and focused around access to education (e.g. learning the language, undertaking a Higher Education degree) or employment.

Over and above tangible assets, the acquisition of more intangible assets - particularly in relation to community networks, rules and 'norms' was also evident (Moser

\footnotetext{
${ }^{1}$ Most of the respondents in Tokyo hold the "Engineer/Specialist in Humanities/International Services" visa, the most common work visa category for highly-educated migrants.
} 
2007, 2008). For example, in Tokyo, most interviewees were single and had entered Japan as students, working holiday makers or interns and only in few cases came directly with a work visa. This relatively flexible and transitional stage in the life cycle allowed them to travel the country, to acquire language proficiency in Japanese and to form close friendships; furthermore, a few migrants met their later spouse during this period of extended youth.

Thus emotional and practical investments - involving the generation of tangible and intangible assets - in individuals' cities of residence generally accumulated over time and informed further decisions to stay or leave. Upon graduation from their university program or internship, migrants' rationales to stay were reasonably uniform. For example, Anna, (Romanian, female), explained her job-hunting activities in Tokyo following graduation from a four-year bachelor program in Japan as follows: "Better you continue what you started than going back and later regretting because it's harder to come back later." Hence those who had obtained a degree or work experience in a Japanese institution highlighted how the efforts of learning the Japanese language, forming networks and obtaining knowledge of "how things work [ed] in Japan" would be 'wasted' upon return.

Similar to EU migrants in Japan, in the UK interviewees also highlighted the importance of assets as reasons to stay. With reference to tangible assets, EU migrants in Glasgow, Edinburgh and Birmingham highlighted how they had made significant investments in purchasing and renovating their current property and hence many felt there was no reason to move. Reference was also made to accessing further and higher education (e.g. acquiring a Scottish degree), access to the labour market, and 'in place' career / work experience opportunities in shaping practices of staying.

In relation to intangible assets, the expansion of migrants' social networks via education, work or partners / friends helped to further embed individuals 'in place'. In Birmingham, the importance of intangible and tangible assets was also apparent: migrants with families noted how place-specific social networks had served to 'smooth' the arrival process as family members had provided assistance with accommodation and initial orientation to the city. As their familiarity with the city grew and as participation in the labour market was secured, they moved into their own accommodation elsewhere in the city.

The risk of wasting accumulated tangible and intangible assets and the need to start life either back in the country of origin, or at a new destination "from scratch", therefore played an important part in migrant decisions to stay. Interviewees in Birmingham highlighted how decisions to stay were informed by the perceived costs of moving away, as described by Manuel (Spanish, male): "If I ever move out of this house I am moving back to Spain. But it is unlikely as in Spain jobs are inaccessible. Jobs are a lottery?" Consequently, potential risks of leaving were also related to the feelings of the unknown, anxiety and uncertainty associated with starting life at a new destination or returning to their home country, as described by Marta (Polish, female) living in Glasgow: "I feel anxious about the idea of going back and had no idea what I would do there, I would need to start from scratch again, and I don't have energy to do so."

While interviewees in the UK highlighted the important role of acquiring and accumulating economic assets in shaping decisions to stay, in Tokyo finding employment was often challenging due to language barriers that limited job opportunities to sectors such as the language industry or headhunting where work was conducted in English. 
Nevertheless, after many years of working in Japan continuously most migrants had built a career that reduced concerns over the renewal of their (time-limited) work visa. As Emilio, who had become fairly knowledgeable of life in Japan after 7 years of staying and whose closest significant other was his Japanese girlfriend, remarked when his five-year work visa neared expiry "[I am] not worried, on the contrary I hope they'll renew [my visa] to a 10 year one." Thus, processes of staying were often being shaped by simultaneous processes of embedding and dis-embedding (Ryan 2018) and with challenges of being able to work and securing tangible economic assets being offset by the generation of more intangible cultural and social assets and a belief over time that they would secure a visa to stay in Japan long-term. Migrants' belief in the trouble-free renewal of their visa was also encouraged by Japan's increased intake of migrants and the relative ease with which socalled skilled work visa have become accessible to obtain or renew (Oishi 2020).

The findings from all three studies also demonstrated that when migrants' biographies became entangled with those of significant 'others', this challenged notions of staying or returning as being a product of individual decisions. Staying decisions were often shaped by partners who had travelled insitu (England, Scotland), as well as partners, family or friends who were either already in the new country of residence or who they had met once they had migrated (all three case studies). Consequently, many interviewees articulated the importance of their partner, family or friends in decisions to migrate and in relation to their reasons for staying. These social relations created an intangible asset and were seen as a key emotional support mechanism without which they would have gone back 'home.' For example Marianne (French, female), who had moved to Tokyo independently, admitted that "[I think] quite a lot 'why am I here?" but had abandoned the idea of leaving Tokyo when her relationship with her South Korean partner grew stronger. With Japanese as the couple's only common language of fluency and thus, Tokyo the only realistic option for a joint life where each could potentially forge a reasonable career, Marianne's life became bound up with and linked to that of her future spouse whose place-specific employment in Tokyo's banking industry was developing at the time.

Hence staying needs to be understood as a relational process that is informed by individual biographies that are entangled with the biographies of significant others, including partners but also children. For example, studies on Polish families in the UK (White 2011) emphasize the role of children in decisions about staying and settling in the UK and suggest that many families extend their stay in the UK because they do not want to disrupt their children's education. This was evident in the case study areas in the UK where participants' decisions to stay were related to the importance of stability of their children's schooling, but also their perceived future economic prospects and established friendships. As stated by Agata (Polish, female) in Glasgow:

My children started school here, they have friends here, Glasgow is their home, so even though I don't see it as my home, I will stay for them, for their future here. I don't need to like it, they are my priority.

The importance of children for staying in Tokyo was not as clear. While children were a reason for several participants to plan their near future in the city, namely the period of nursery and kindergarten, the majority of interviewees had mixed feelings about schooling in Japan. In the words of Alexiou (Greek, male): 
[I will] probably stay here in Japan, [I have] no plans moving for now. If I have kids, maybe [I would move to] an English-speaking country? [ ... ] For sure I wouldn't like my kids to be like average Japanese, like shy and not being fluent in foreign languages.

Consequently, Alexiou and many others commented on Japan's perceived closeness which contrasted with their own experiences of travelling and fluency in speaking several languages as well as their own upbringing in (what was for them) more outspoken / individualistic societies; a bifocal view of culture in education often claimed by scholarship (Tobin et al. 2011).

In sum, the accumulation of a diverse range of tangible and intangible assets is a dynamic process which can shape the ways in which the biographies of individuals may unfold in the context of particular places. As such, assets can act as a 'stock' which provide individuals with the capability and agency to act and to use such resources in a diverse range of situations to make longer-term plans. Migrant staying was thus an ongoing reflective process that involved a 'weighing up' of migrant's current position and assets 'in hand' in contrast to future opportunities and challenges of securing such assets. Our findings also illustrate the complex role of different types of assets in shaping migrant's experiences of staying. As Emilio's example illustrates, a potential lack of legal and economic assets (work visa and consequently, employment) was compensated by intangible assets in the form of social networks and familiarity with the norms of the host country and which served to contribute to staying processes. Similarly, the examples of Alexiou, Agata and Marianne illustrate that migrant's linked lives may equally prompt desires to stay or to move on. Consequently, the relevance of linked lives flows through the evolution of migrants' assets, as well as biographies and anchors, as we discuss further below.

\section{Changing biographies of people and places}

The importance of changing places on processes of settlement was evident in all three case study areas. For example, in Tokyo there has been a sharp rise of foreign tourists, international students and migrants from various countries in the past ten years and Japanese people's gradual familiarization with the foreigners in their midst had in one respondent's words created "significantly more comfortable" living conditions. Some participants with limited Japanese language proficiency also remarked how Tokyo's rapid internationalization had now allowed them to handle more daunting issues of life in Japan (such as Doctors appointments), and which previously had required proficiency in the Japanese language. Their narratives therefore confirm that Japan's efforts to internationalize have reduced at least some of the longstanding obstacles for migrant staying such as the limited offer of foreign language services or internationally trained medical doctors (Oishi 2012). That said, many of the EU respondents additionally relied on bilingual friends or family who formed part of the rapidly growing foreign and multilingual Japanese community in Tokyo when dealing with complicated bureaucratic issues such as tax matters. Others gratefully emphasized the patience and helpfulness of Japanese service personnel whom it was suggested were trying their best to support the rising numbers of foreign customers. 
In the UK - and taking Birmingham as an example - the evolving nature of migrantdriven 'superdiversity' (Vertovec 2007) and the changing biography of the city had additionally served to shape processes of staying over time. Interestingly, few participants felt that the city had become too diverse and thereby avoiding dis-embedding taking place as a result of new migration flows. Rather, decisions to stay were being consolidated as a result of the increasing diversity of infrastructure (e.g. shops, specialist services, etc.): "it has certainly made things easier because the shops are now on my doorstep - they have Portuguese food so I don't have to get this from Portugal" (Tiago, Portuguese male). Moreover, those more visibly different argued that it was too risky to move elsewhere given that they perceived that levels of discrimination and racism had increased since they had moved to Birmingham. Hence the increasing superdiversification of the population was also contributing to processes of staying.

Individuals' biographies, too, were evolving and intersecting with the changing biographies of place. Given that most participants migrated at a young age, this was leading to a greater proportion of key life-cycle events taking place in their new country of residence (e.g. starting a relationship, birth of children, schooling) and increasing the importance of changing biographies on the settlement process. In essence, time, migration and processes of staying were intertwined in multiple ways, as described by Franciszek (Polish, male), living in Scotland:

Initially there was a period of professional interest and development ... ...and that's what kept me here ... ..then it was related to the fact that my partner started studying ... I didn't consider moving to Warsaw (Poland) because I knew she would be studying for a period of time, even though my work was up and down at that time. Working as an architect, it all depends on the project ... ..some were long-term and so I wanted to carry on working on them until they're finished.

From this quote we can ascertain that Franciszek did not discuss his overall stay in Scotland but instead referred to a combination of biographical experiences. Franciszek's testimony highlights the significance of temporal dimensions of migrants' experiences for understanding staying. Whilst the relation between time and migration has been touched upon previously (e.g. Cwerner 2001; Robertson 2015; Sheller 2019), our research moves further by highlighting how staying - following migration - emerges as a set of temporal dimensions not directed towards permanent settlement; rather it involves the fulfilment of short-term goals or plans that in aggregation lead individuals to stay in the longer term. As such, the experiences of staying involved differentiated sequences of actions, experiences and encounters. These are contextualized in relation to the (also) changing biographies, values and aspirations of individuals and places, and which are often entwined. Exemplifying the latter, we see how migrant biographies in Birmingham evolved in relation to the on-going 'diversification of diversity' (Vertovec 2007) in the city:

I come from a little town in Spain ... everybody there is white like me. When I came here first it was a big impact but now I've got used to being around people of different ethnicities, people speaking worse or better English than me, young people, old people ... and how it constantly changed. And I love it (Manuel, Spanish male). 
This was also true in Tokyo where many migrants noted how they had come to see life in the city as their "comfort zone" which they assumed would be difficult to discard as their resumes had been shaped by training in Japanese institutions and through work experience in Japanese firms. Kathrin (German, female) had left Tokyo after 3 years of working to return to Germany but had returned after only 2 years. While in Germany she had reflected on the attraction of Tokyo as a place to live and had also married her German boyfriend (who also had a Japanese degree). Both had subsequently secured well paid jobs in Japan and this was now viewed as a reason to stay. Hence it is evident that individual plans and aspirations change with time but also in the context of changing places: with 'global jobs' in Tokyo increasing rapidly, Kathrin's rationale captures the overlapping temporalities of changing biographies and changing places. Her comment that "also financially, it makes more sense for us to stay [in Tokyo] if we compare with our friends at home" underlines how their biographies had adapted more to the new face of Tokyo rather than the domestic German labour market. It also alerts us once again - to the importance of linked lives - in this case Kathrin's partner but also the experiences of their friends - bringing the reciprocity between changing place and changing biographies to the fore.

Thus overall, it was evident that migrant staying was temporal as well as contextual and that processes of staying were dependent on how migrant biographies - as well as the places in which they lived - changed over time and in relation to others' lives unfolding (also see Halfacree and Rivera 2012). But the research also provided new insights which demonstrated how staying was often incremental rather than a deliberate and 'once and for all' process - facilitated (and also undermined) as a result of a culmination of changing needs, values, actions and experiences, as well as assets. Sometimes staying was opportunistic or deliberate; at other times it was much more pragmatic and involving "learning to live with life in the city, whatever the problems" (Jolena, Polish female).

\section{Anchors and sense of belonging}

Migrants' evolving assets and biographies can also inform more subjective feelings associated with social, emotional and psychological stability and feeling 'settled down'. As explained earlier, Grzymala-Kazlowska (2016) refers to such 'footholds' as 'anchors'. Anchors have some parallels with the psychological (intangible) aspect of migrant assets yet can be better conceived as a state of becoming that migrants may achieve over time and contribute to feelings of being 'settled down'. Put differently, the sense of belonging that migrants may generate over time as a result of the changing biographies of individuals or places and/or the generation or loss of assets cannot simply be exchanged or replaced: for example, an intangible asset such as a community network may be replaced with the development of a different community network. However, this is not possible in terms of more subjective feelings of belonging and which may emerge over an extended period of time.

Moving beyond previous research on the different types of anchors of relevance in the context of settlement (Grzymala-Kazlowska and Phillimore 2018), our analysis demonstrates the relative importance of daily and weekly routines and 'rhythms' as anchors in connecting migrants to specific places and how these may change as individuals' biographies and places of residence change. For some, 'feeling settled' set in once 
individuals had obtained sufficient assets that rendered existential anxieties redundant. But for many others, feeling settled was the moment from which they knew their neighbourhood or city 'by heart' and / or no longer needed a native speaker's help and hence felt secure enough as to think about their life less as that of an outsider but as a 'local' to their current place of residence (Buhr 2018). Across all three case study areas it was apparent that feelings of security that anchored migrants to their place of residence related to familiarity, predictability and ways of 'knowing the city' or neighbourhood. For example, in Tokyo getting to know the city nurtured migrants' sense of ease, independence and feelings of freedom and convenient living, as expressed by Lena (German, female):

When I was here in high school, I sometimes couldn't sleep at night. At 2 am I thought "I'll now go and get myself an ice cream." [ ... ] I left the house and went to the [convenience store], alone, as an under-aged girl. I bought the ice cream I wanted and sat outside [and] thought "this is the greatest freedom I have ever felt." I got what I wanted, when I wanted it, and I was outside alone and felt safe. And this is what keeps me staying. This is the lifestyle I have here.

Likewise, in Birmingham a majority of interviewees highlighted that as their knowledge and experience of navigating the city had improved over time, this had also been fundamental in decisions to stay. In this context, a feeling of convenient living was also linked to issues of access. For example, Ania (Polish, female) in Birmingham noted how "when I first came here, I was totally lost. I am much more confident now". Consequently, individuals' increasing ability to travel elsewhere in the city was seen as being fundamental in shaping decisions to stay as they were able to access leisure services elsewhere, to meet friends and to access a range of services in the city centre.

Perceived freedom from 'knowing the city' and neighbourhood fostered a sense of 'being home' and became a powerful force in shaping staying. This was the case for many migrants in Glasgow, who emphasized the importance of daily routines, rhythms and / or the repetitiveness of everyday actions that made them feel familiar and secure: "this is where I go shopping, this is where I go for a beer, this is where I go to work ... we find spaces which are familiar to us and where we like returning; it gives a sense of peace and order" (Szymon, Polish male).

Importantly, the place-specific daily routines and pace of daily interactions could also be understood as set of temporal experiences that migrants had to adjust to over time. As individual and place biographies changed in terms of access to the labour market, or in respect of their networks and relations with others, this shaped routines and rhythms of relevance to work, leisure or the home. Again, in the words of Szymon:

I like coming for a coffee here because there's a nice man that has a chat with me, I can talk to a neighbour for a moment, I can bump into a friend, and over the years I've lived here certain places and faces became familiar and I think, yes, this is my town.

Therefore, it was through the development of everyday practices, rhythms and routines that participants like Szymon achieved a sense of familiarity that contributed 
to feelings of security and being 'settled down'. These feelings, however, require the ability to navigate and master everyday life in a foreign language. Moreover, migrants' considerations of return or onward migration introduced uncertainty about the future. A number of respondents across all three case studies noted how the idea of moving on and starting life at an unknown destination or returning to their country of origin would require them to develop new, place-specific assets and anchors, heightening feelings of anxiety and uncertainty. This, once again, meant that there was an on-going weighing up of influences associated with staying or moving.

To summarize, a prolonged period of time by migrants in their country of destination led to anchors being developed in relation to 'ways of knowing' their place of residence and which fostered feelings of familiarity of their country, city or neighbourhood. Ways of knowing and familiarity also shaped routines and the predictability of their actions and behaviours. It also influenced their perceptions of the actions and behaviours of others. Consequently, this highlights how anchoring can be shaped by the linked (everyday) lives of others - in this case, the 'faces' and rhythms associated with other migrants and non-migrants in the city - and which in turn contributed to their own processes of staying in respect of feelings of stability, security and "being settled". These anchors became precious commodities over time and which migrants were often reluctant to trade in as part of ongoing deliberations and a 'weighing up' of their current position vis a vis return or onward migration. Thus, the unfolding of the changing biographies of migrants and the places in which they now lived - as well as those where they lived previously - shaped processes of anchoring. Footholds for sociopsychological stability and security were generated through their interactions with different dimensions of place and other individuals in their current residential context and which were perceived as allowing them to function effectively in their new life setting.

\section{Discussion and conclusions - a new conceptual framework for migrant staying}

In the context of the Special Issue, this paper has provided new insights into the importance of migrant staying - as opposed to the attraction and selection of foreign labour per se - to meet challenges of sustaining economic growth and to address sector-specific labour market shortages in Japan and the UK. Such countries were selected for analysis given commonalities of weak economic growth, an ageing population, the increasing superdiversity of their populations (and with Tokyo being focused upon given its elevated levels of diversity compared to the rest of the country) and subsequent attempts to address labour shortages through the use of migration policy measures (Ozgen et al. 2019). However, in contrast to existing studies which have focused on the circularity, temporariness and liquidity of EU migrants (see Ryan 2018; Beaverstock 2002), our paper developed an alternative perspective which considered processes of staying among EU migrants in destination countries. In such a way, the paper also considered aspects of staying which occurred after a period (or periods) of mobility and which the migrants perceived as neither permanent nor definite.

From our findings, we therefore argue that staying is an on-going process driven and informed by three key elements: assets, changing biographies of individuals and places, and anchors, as well as through 'linked lives' which is a consistent presence in shaping 
processes of staying. This is summarised in Fig. 1 below, which provides a new conceptual framework for understanding the temporalities of migrant staying.

The framework is illustrative rather than representative of migrant staying processes, conceptualized as the subjective experience of a multiplicity of 'lived time' events (Robertson 2015, p. 1918). Thus, we recognize the contextuality and temporality of staying and use the framework as a heuristic tool for identifying different dimensions that shape migrant's staying (or indeed, leaving) experiences and their relations to each other. In addition, the framework deliberately has no start or end point in order to underline the importance of time in the process of staying. Time shapes people as it shapes places and people's changing biographies and changing places shape each other. Importantly, the three influences shaping migrant staying overlap, emphasising the inter-relations between each. This recognition allows us to discuss how staying or indeed onward mobility occur not just as a result of single life events but as a consequence of the intersecting temporalities of multiple events, experiences and practices which occur over time and at different pace, and through changing assets, anchors, places and spaces. Staying involves the fulfilment of short-term goals or plans that in aggregation may lead individuals to stay long-term. Inherent within the framework is a recognition of the different components of time - for example, time as 'duration', time as 'rhythm' - which can shape migrant's decisions to stay and offering further insights into the temporalities of migration which have increasingly been recognised (Cwerner 2001; Robertson 2015; Sheller 2019).

Whilst the framework offers the potential for transferability into other contexts of immigration and / or emigration, further research is required on the relative importance of migrant biographies, assets and anchors under different immigration welfare and labour market conditions. This includes exploring practices of staying - and influences therein - where migration takes place between low and middle income countries to the most economically developed countries and vice versa, and where routinized well-being may be less normalised for individuals. In addition, it also includes further

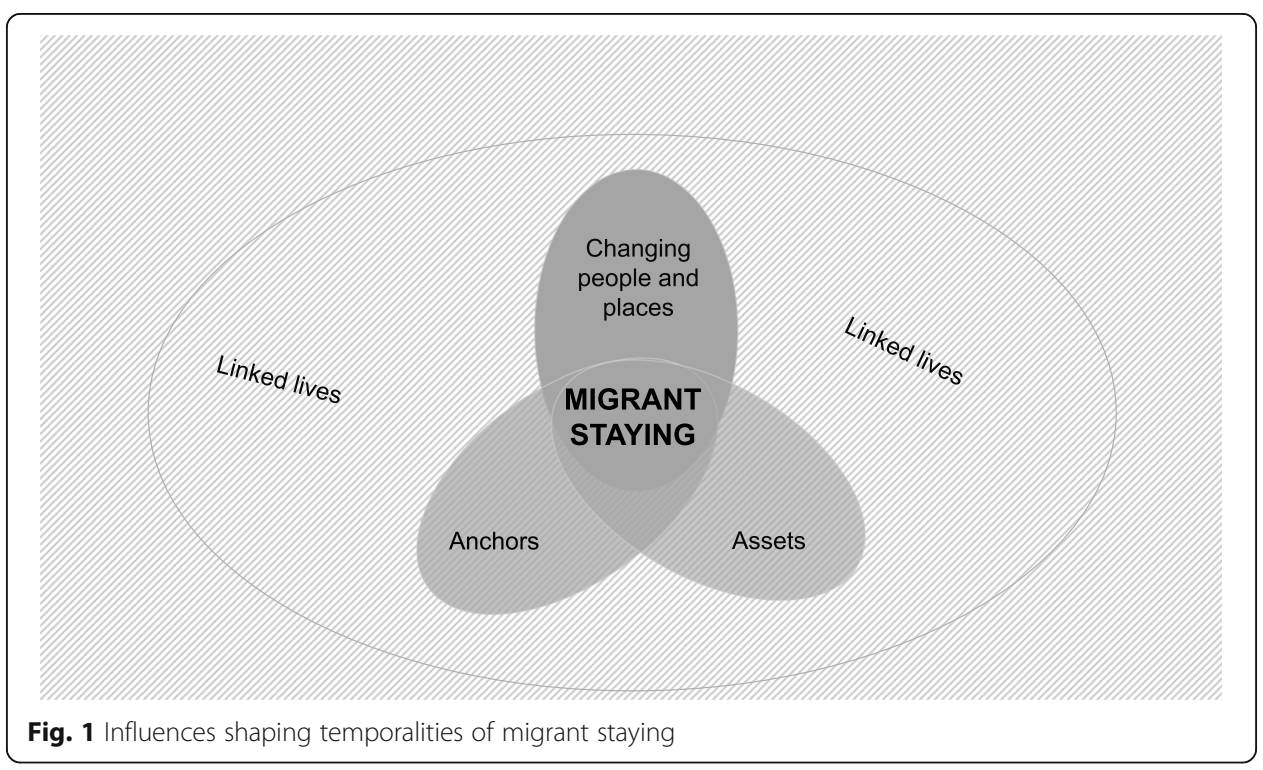


consideration of the impact of changing immigration systems on individuals 'rights to remain' and their legal status.

For example, in Japan the share of foreign nationals in the labour force is currently much lower than in the UK. But for the first time, the government has outlined strategies to open pathways to permanent residency to a significantly larger number of types of migrants with wide-ranging competences and work experience (Oishi 2020). However, given the fact that Japan is currently struggling to retain many migrants the framework could be useful for future studies in order to generate a more detailed understanding of the influences shaping processes of staying for migrants in specific high and low paid sectors. Moreover, whilst this paper focuses on documented migrants, there is also value in exploring the influences shaping staying processes for undocumented migrants in Japan and the potential opportunities or challenges associated with 'regularising' such individuals on either a temporary or permanent basis.

In contrast, whilst the UK has been dependent on foreign labour for a longer period of time, it is likely that there will be increasing regulation of low skilled migrants (from the EU) post-Brexit and a re-assertion of the need to attract highly skilled migrants from across the world. Further research will therefore be required on the temporalities of migrant staying as migration routes change with the introduction of a points-based visa system in countries such as the UK and elsewhere, and how a reliance on visas (and their extension) serve to challenge individuals' feelings of being 'settled down'. In turn, such changes in immigration policies - and influences therein - will also impact on the staying practices of both documented and undocumented workers and strategies of migrant retention.

\section{Acknowledgements}

We would like to thank Jenny Phillimore and Gracia Liu-Farrer for useful comments and suggestions that helped developing the paper further.

Authors' contributions

All authors made an equal and substantial contribution to the design of the paper; data acquisition and analysis, interpretation of data and drafting of all work; all approve the submitted version.

\section{Funding}

The collaborative work on this manuscript was made possible by the ESRC grant ref.: ES/S013245/1 for the NODE UK Japan Network and from the Japan Foundation Grant for Intellectual Exchanges and Conferences. The research in Birmingham, UK was funded by the Leverhulme Trust (RF-2015-418 "The importance of super-diverse places in shaping residential mobility patterns"). The research in Glasgow and Edinburgh was supported by the Economic and Social Research Council (grant number RES-625-25-001). The research in Japan was funded by the Japanese Society for the Promotion of Science (19 K13890). None of the funding bodies was involved in the design, collection and / or interpretation of data.

Availability of data and materials

The datasets used and/or analysed during the current study are available from the corresponding author on reasonable request.

Competing interests

The authors declare that they have no competing interests.

\section{Author details}

${ }^{1}$ Department of Japanese Studies, Institute of Asian and Oriental Studies, University of Zurich, Zürichbergstrasse 4 CH-8032 Zürich, Switzerland. 'Keele University, Room WS1.36, William Smith Building, Keele, Staffordshire ST5 5BG, UK. ${ }^{3}$ Hamilton International Technology Park, South Lanarkshire G72 OLH, Scotland, UK.

Received: 27 August 2020 Accepted: 2 February 2021

Published online: 17 May 2021

References

Anderson, B. (2007). A very private business: Exploring the demand for migrant domestic workers. European Journal of Women's Studies, 14(3), 247-264. 
Beaverstock, J. V. (2002). Transnational elites in global cities: British expatriates in Singapore's Financial District. Geoforum, 33(4), 525-538.

Buhr, F. (2018). Using the city: Migrant spatial integration as urban practice. Journal of Ethnic and Migration Studies, 44(2), $307-320$.

Collett, E. (2013). The integration needs of mobile EU citizens. Impediments and opportunities. Brussels: Migration Policy Institute Europe.

Coulter, R., \& Scott, J. (2015). What motivates residential mobility? Re-examining self-reported reasons for desiring and making residential moves. Population, Space and Place, 21, 354-371.

Coulter, R., van Ham, M., \& Findlay, A. M. (2013). New Directions for Residential Mobility Research: Linking Lives through Time and Space (IZA discussion paper, no. 752). Bonn: IZA.

Cwerner, S. B. (2001). The times of migration. Journal of Ethnic and Migration Studies, 27(1), 7-36.

Elder, G. H. (1994). Time, agency, and social change. Social Psychology Quarterly, 57, 4-15.

Engbersen, G., Leerkes, A., Scholten, P., \& Snel, E. (2017). The intra-EU mobility regime: Differentiation, stratification and contradictions. Migration Studies, 5(3), 337-355.

Faist, T. (2013). The mobility turn: A new paradigm for the social sciences? Ethnic and Racial Studies, 36(11), 1637-1646.

Favell, A. (2008). The new face of east-west migration in Europe. Journal of Ethnic and Migration Studies, 34(5), 701-716.

Giniewicz, J., \& Castiglione, C. (2011). State response to transnational asset accumulation: The case of Argentina. Bulletin of Latin American Research, 30(2), 133-147.

Griffiths, M., Rogers, A., \& Anderson, B. (2013). Migration, time and temporalities: Review and prospect (COMPAS Research Resources Paper, March 2013). Oxford: Centre on Migration.

Grzymala-Kazlowska, A. (2016). Social anchoring: Immigrant identity, security and integration reconnected? Sociology, 50(6), 1123-1139.

Grzymala-Kazlowska, A. (2018). From connecting to social anchoring: Adaptation and 'settlement' of polish migrants in the UK. Journal of Ethnic and Migration Studies, 44(2), 252-269.

Grzymala-Kazlowska, A., \& Phillimore, J. (2018). Introduction: Rethinking integration. New perspectives on adaptation and settlement in the era of super-diversity. Journal of Ethnic and Migration Studies, 44(2), 179-196.

Guest, G., MacQueen, K. M., \& Namey, E. E. (2012). Applied thematic analysis. Thousand Oaks: Sage.

Halfacree, K. H., \& Rivera, M. J. (2012). Moving to the countryside and staying: Lives beyond representations. Sociologia Ruralis, $52(1), 92-114$

Hof, H. (2019). The Eurostars go global: Young Europeans' migration to Asia for distinction and alternative life paths. Mobilities, 14(6), 923-939.

Holbrow, H. J., \& Nagayoshi, K. (2018). Economic integration of skilled migrants in Japan: The role of employment practices. International Migration Review, 52(2), 458-486.

Holdsworth, C. (2013). Family and intimate mobilities. London: Springer.

King, R., Lulle, A., Sampaio, D., \& Vullnetari, J. (2017). Unpacking the ageing-migration nexus and challenging the vulnerability trope. Journal of Ethnic and Migration Studies, 43(2), 182-198.

Lessard-Phillips, L., Roberts, G., \& Phillimore, J. (2019). Policy and politics of migration post-1945 (IRiS Working Paper Series, No. 34/2019). Birmingham: Institute for Research into Superdiversity.

Liu-Farrer, G. (2020). Immigrant Japan. New York: Cornell University Press.

Looker, E., \& Naylor, T. (2009). At risk' of being rural? The experience of rural youth in a risk society. Journal of Rural and Community Development, 4(2), 39-64.

Massey, D. (2005). For space. London: Sage.

Migration Advisory Committee (2020). A points-based system and salary thresholds for immigration, London. Retrieved from https://assets.publishing.service.gov.uk/government/uploads/system/uploads/attachment_data/file/873155/PBS_and_Sala ry_Thresholds_Report_MAC_word_FINAL.pdf. Accessed 05 May 2020.

Moser, C. (2007). Asset accumulation policy and poverty reduction. In C. Moser (Ed.), Reducing global poverty: The case for asset accumulation (pp. 83-103). Washington: Brookings Institution Press.

Moser, C. (2008). Assets and livelihoods: A framework for asset-based social policy. In C. Moser, \& A. A. Dani (Eds.), Assets, livelihoods, and social policy: New Frontiers of social policy (pp. 43-81). Washington: The World Bank.

National Institute of Population and Social Security Research (2017). Population projections for Japan (2016-2065): Summany. Retrieved from http://www.ipss.go.jp/pp-zenkoku/e/zenkoku_e2017/pp_zenkoku2017e_gaiyou.html. Accessed 15 June 2020

Erdal, M. B., \& Oeppen, C. (2013). Migrant balancing acts: Understanding the interactions between integration and transnationalism. Journal of Ethnic and Migration Studies, 39(6), 867-884.

Office for National Statistics (ONS) (2019). Revised annual mid-year population estimates, 2001 to 2018. London: ONS.

Oishi, N. (2012). The limits of immigration policies: The challenges of highly skilled migration in Japan. American Behavioral Scientist, 56(8), 1080-1100.

Oishi, N. (2020). Skilled or unskilled? The reconfiguration of migration policies in Japan. Journal of Ethnic and Migration Studies. https://doi.org/10.1080/1369183X.2020.1731984.

Ozgen, C., Liu-Farrer, G., Cole, M., \& Green, A. (2019). Economic migration in the UK and Japan examining the roles of labour shortages, automation, migration policy and demographic agingIRiS (Working Paper Series, No. 32/2019). Birmingham: Institute for Research into Superdiversity.

Pemberton, S., \& Phillimore, J. (2018). Migrant place-making in super-diverse neighbourhoods: Moving beyond ethno-national approaches. Urban Studies, 55(4), 733-750.

Recchi, E., \& Favell, A. (Eds.) (2009). Pioneers of European integration: Citizenship and mobility in the EU. London: Edward Elgar Publishing.

Robertson, S. (2014). Time and temporary migration: The case of temporary graduate workers and working holiday makers in Australia. Journal of Ethnic and Migration Studies, 40(12), 1915-1933.

Robertson, S. (2015). Contractualization, depoliticization and the limits of solidarity: Noncitizens in contemporary Australia. Citizenship Studies, 19(8), 936-950.

Ryan, L. (2011). Transnational relations: Family migration among recent polish migrants in London. International Migration, 49, 80-103. 
Ryan, L. (2018). Differentiated embedding: Polish migrants in London negotiating belonging over time. Journal of Ethnic and Migration Studies, 44(2), 233-251.

Ryan, L., Sales, R., Tilki, M., \& Siara, B. (2008). Social networks, social support and social capital: The experiences of recent Polish migrants in London. Sociology, 42(4), 672-690.

Salamońska, J., \& Recchi, E. (2016). Europe between mobility and sedentarism: Patterns of cross-border practices and their consequences for European identification (Working Paper, EUI RSCAS 2016/50). Migration Policy Centre. Retrieved from http://hdl.handle.net/1814/43545.

Sampaio, D., King, R., \& Walsh, K. (2018). Geographies of the ageing-migration nexus: An introduction. Area, 50(4), 440-443.

Scottish Government (2018). Scotland's Population Needs and Migration Policy: Discussion paper on evidence, policy and powers for the Scottish Parliament. Retrieved from http://www.gov.scot/Publications/2018/02/5490. Accessed 05 May 2020.

Sheller, M. (2019). Afterword: Time is of the essence. Current Sociology, 67(2), 334-344.

Sheller, M., \& Urry, J. (2006). The new mobilities paradigm. Environment and Planning A: Economy and Space, 38(2), 207-226.

Stockdale, A., \& Haartsen, T. (2018). Editorial introduction: Putting rural stayers in the spotlight. Population, Space and Place, 24(4), 1-8.

Stockdale, A., Theunissen, N., \& Haartsen, T. (2018). Staying in a state of flux: A life course perspective on the diverse staying processes of rural young adults. Population, Space and Place, 24, e2139.

Thomas, M., Stillwell, J., \& Gould, M. (2015). Modelling multilevel variations in distance moved between origins and destinations in England and Wales. Environment and Planning A: Economy and Space, 47(4), 996-1014.

Tobin, J., Hsueh, Y., \& Karasawa, M. (2011). Preschool in three cultures revisited: China, Japan, and the United States. Chicago: University of Chicago Press.

Tseng, Y.-F. (2020). Becoming global talents? Taiwanese white-collar workers in Japan. Journal of Ethnic and Migration Studies. https://doi.org/10.1080/1369183X.2020.1731986.

Valentine, G., \& Sadgrove, J. (2012). Lived difference: A narrative account of spatiotemporal processes of social differentiation. Environment and Planning A: Economy and Space, 44(9), 2049-2063.

Vargas-Silva, C. \& Rienzon C. (2020). Migrants in the UK: An Overview. The Migration Observatory Briefing. Retrieved from https://migrationobservatory.ox.ac.uk/resources/briefings/migrants-in-the-uk-an-overview/. Accessed 8 Feb 2021.

Vertovec, S. (2007). Super-diversity and its implication. Ethnic and Racial Studies, 30(6), 1024-1054.

White, A. (2011). Polish families and migration since EU accession. Bristol: Policy Press.

\section{Publisher's Note}

Springer Nature remains neutral with regard to jurisdictional claims in published maps and institutional affiliations.

\section{Submit your manuscript to a SpringerOpen ${ }^{\circ}$ journal and benefit from:}

- Convenient online submission

- Rigorous peer review

- Open access: articles freely available online

High visibility within the field

- Retaining the copyright to your article

Submit your next manuscript at $\boldsymbol{\nabla}$ springeropen.com 